\title{
Dorongan Kelangsungan Usahawan Wanita dalam Perusahaan Batik dan Songket
}

(Encouragement for the Sustainability of Women Entrepreneurs in Batik and Songket Businesses)

\author{
Nor Hanim Awang @ Mohd Noor \\ Norfatiha Othman \\ Nor Hayati Sa'at \\ Roslina Ismail \\ (Fakulti Perniagaan, Ekonomi dan Pembangunan Sosial, Universiti Malaysia Terengganu)
}

\begin{abstract}
ABSTRAK
Peningkatan wanita dalam aktiviti perniagaan di bandar dan luar bandar telah menjadi pemangkin utama kepada pertumbuhan ekonomi negara. Golongan wanita di Pantai Timur terutamanya di Kelantan dan Terengganu dilihat agak menonjol memasuki dunia perniagaan. Mereka sangat aktif mengusahakan dua jenis perusahaan berasaskan kraftangan iaitu batik dan songket. Pembabitan wanita di dalam keusahawanan batik dan songket bukan sahaja membantu dalam aspek ekonomi keluarga malah merealisasikan keinginan mereka menjadi seorang usahawan wanita. Kajian ini bertujuan menganalisis dorongan pembentukan usahawan batik dan songket wanita di Malaysia. Reka bentuk kajian kes kualitatif digunakan dengan menggunakan temu bual mendalam dan pemerhatian ke atas 12 orang usahawan batik dan songket yang dipilih melalui kaedah pensampelan snowball di Kelantan dan Terengganu. Hasil temu bual mendalam dianalisis secara tematik manakala pemerhatian dianalisis melalui catatan nota lapangan, gambar visual dan rakaman suara. Hasil kajian menunjukkan dorongan kepada pembentukan usahawan batik dan songket wanita, asasnya adalah pengaruh keluarga yang terdiri daripada proses sosialisasi keluarga, kemahiran keluarga, minat dan sumbangan kepada keluarga. Oleh itu, dorongan mereka dalam keusahawanan batik dan songket dapat dikaitkan dengan asuhan dan pendedahan berterusan daripada keluarga bagi membentuk usahawan wanita. Melalui aktiviti keusahawanan yang diceburi, usahawan wanita berpotensi menjana pendapatan yang tinggi terhadap keluarga mereka. Keuntungan yang tinggi yang diperolehi melalui industri batik dan songket juga memberi dorongan kepada golongan wanita lain untuk turut serta dalam keusahawanan batik dan songket di Malaysia.
\end{abstract}

Katakunci: Penglibatan wanita; batik dan songket; kraftangan; usahawan wanita; Pantai Timur

ABSTRACT

The increase of women in business activities in urban and rural areas has been a major catalyst to the country's economic growth. Women in the East Coast, especially in Kelantan and Terengganu, are seen to be quite prominent in the business world. They are very active in two types of handicraft-based enterprises, namely batik and songket. The involvement of women in batik and songket entrepreneurship not only helps in the economic aspect of the family but also realizes their desire to become a woman entrepreneur. This research aims to determine the encouragement in the formation of women batik and songket entrepreneurs in Malaysia. The qualitative case study design was used by using in-depth interviews and observations on 12 batik and songket entrepreneurs selected through the snowball sampling method in Kelantan and Terengganu. Information obtained from in-depth interviews was analyzed thematically while observations were analyzed through the inclusion of field notes, visual pictures as well as voice recordings. The results showed that the encouragement of the formation of batik and songket women entrepreneurs, the basis is the influence of the family which consists of the process of family socialization, family skills, interests, and contributions to the family. Therefore, their involvement in batik and songket entrepreneurship can be attributed to the constant upbringing and exposure from the family to form women entrepreneurs. Through entrepreneurial activities, women entrepreneurs have the potential to generate high income for their families. The high profits earned through the batik and songket industry also encourage other women to participate in batik and songket entrepreneurship in Malaysia.

Keywords: Women involvement; batik and songket; handicraft; women entrepreneur; East Coast

\section{PENGENALAN}

Penglibatangolonganwanitadalamaktivitikeusahawanan sebagai faktor berpusat yang menjadi penyumbang signifikan ke atas ekonomi negara terutamanya kepada proses pengeluaran, penggunaan dan pengagihan. Ia selari dengan adanya peluang terbuka yang diberikan oleh kerajaan untuk mempertingkatkan taraf hidup dan penglibatan dalam aktiviti ekonomi wanita (Sharifah Nazira 2012; Jariah et al. 2010; Malaysia 2001). Peranan Kementerian Pembangunan Wanita, Keluarga dan Masyarakat dibantu Jabatan Pembangunan Wanita (JPW) sebagai agensi kerajaan telah menggalakkan penyertaan wanita dalam aktiviti ini. Menurut Jabatan 
Statistik Malaysia (2020) Perusahaan Kecil Sederhana merupakan penyumbang kepada ekonomi negara di bawah perdagangan borong dan runcit. Perusahaan Batik dan songket adalah salah satu bidang PKS negara. Unit Perancang Ekonomi dan Jabatan Perangkaan Malaysia (2020) dalam tempoh sepuluh tahun iaitu dari tahun 2010 hingga tahun 2020 menunjukkan kadar penyertaan tenaga kerja wanita semakin meningkat dari 47 peratus kepada 59 peratus. Misalnya Othman dan Dawood (2020) di Kelantan 95 peratus usahawan terdiri daripada golongan wanita.

Manakala kadar penglibatan wanita dalam pasaran buruh pada tahun 2015 adalah 54.1 peratus meningkat kepada 55.8 pada tahun 2020. Begitu juga dengan Indeks Jurang Gender Malaysia mencatatkan peningkatan kepada 70.9 peratus pada tahun 2020 (Jabatan Statistik Malaysia 2020). Menyitir pandangan Noraini (2010), peningkatan bilangan ini dilihat agak menonjol oleh usahawan wanita di Pantai Timur terutamanya di Kelantan dan Terengganu yang mengusahakan tekstil. Peningkatan bilangan tersebut juga disebabkan oleh penguasaan wanita Melayu dalam perniagaan yang menunjukkan hampir 100 peratus golongan wanita di Pantai Timur terlibat dalam aktiviti perniagaan. Penguasaan wanita di dalam perniagaan batik songket juga adalah berdasarkan pengalaman sejarah dan aspek budaya yang merupakan faktor utama yang menentukan kadar dan skop penglibatan wanita di dalam aktiviti ekonomi. Negeri-negeri yang mula menjalankan perusahaan tekstil ialah Kelantan dan Terengganu yang menghasilkan tekstil yang berbentuk batik dan songket (Abd. Rasid \& Ahmadrashidi 2012). Menurut Perbadanan Kraftangan Malaysia di Kelantan dan Terengganu (2015) terdapat sejumlah 128 orang usahawan wanita yang berdaftar di Kelantan terlibat dalam perusahaan batik dan songket manakala sejumlah 330 orang usahawan wanita mengusahakannya di Terengganu.

Di Malaysia penglibatan Wanita dalam perniagaan sudah lama wujud misalnya di negeri-negeri Pantai Timur Semenanjung seperti Kelantan dan Terengganu iaitu perniagaan di pasar-pasar, pemborong, peruncit dan peniaga di kaki lima banyak dimonopli oleh kaum Wanita (Anis \& Sharifah 2020). Budaya keusahawanan yang tinggi ini dapat dikaitkan dengan gaya hidup orang Melayu pada masa lalu yang diwarisi sejak zaman-berzaman. Orang-orang Melayu pada ketika itu kuat terikat dengan tradisi yang dianggap sukar untuk mengalami perubahan tidak seperti masyarakat di negara barat (Parkinson 1967). Analisis oleh Ong (1970) mendapati perusahaan menghasilkan batik (tekstil) di Semenanjung Malaysia hanya bermula pada tahun 1930an iaitu di Kota Bharu, Kelantan. Manakala di Terengganu pula, perusahaan batik mula diperkenalkan pada tahun 1939 di Kuala Terengganu, Terengganu. Kebanyakan perusahaan batik ini tertumpu dan berkembang dengan pesatnya dalam kalangan orang-orang Melayu di negeri Kelantan dan Terengganu.

Namun, terdapat keunikan dalam kalangan wanita yang berada di Pantai Timur khususnya Kelantan dan
Terengganu. Sebahagian besar pengusaha batik dan songket wanita merupakan kesinambungan daripada perniagaan warisan keluarga mereka yang telah bertapak sejak lebih daripada 100 tahun (Wan Hashim 1996). Walaupun sehingga kini, terdapat kajian khusus mengenai usahawan wanita yang menfokuskan kepada pelbagai bidang seperti Nor Aini (2010), yang menjalankan kajian mengenai ekonomi wanita dan perniagaan pasar di Kelantan; Zaimah dan Sazuani (2017) meneliti tentang tahap keupayaan usahawan dalam perusahaan kecil dan sederhana di Kuala Terengganu serta Khatijah et al. (2018) yang menganalisis niat keusahawanan dan keperibadian dalam kalangan usahawan wanita di Terengganu. Justeru, kajian ini ingin mengusulkan mengenai usahawan batik dan songket dengan melihat dorongan pembentukan usahawan wanita di Pantai Timur, Semenanjung Malaysia iaitu di Kelantan dan Terengganu.

\section{TINJAUAN LITERATUR KEUSAHAWANAN WANITA}

Aktiviti keusahawanan yang melibatkan golongan wanita dalam industri kraf dengan pelbagai isu dan latar belakang telah dibahaskan oleh sarjana sehingga sekarang. Walau pun begitu, terdapat isu-isu tertentu di latar kajian yang berbeza kurang diberi perhatian misalnya usahawan wanita batik dan songket ini. Justeru, kajian ini bertujuan menganalisis dorongan pembentukan usahawan batik dan songket wanita di Malaysia. Chowdhury (2018) meneliti cabaran dan rintangan yang dihadapi oleh usahawan wanita yang diperlakukan secara berbeza daripada lelaki, khususnya melibatkan pinjaman dari institusi kewangan. Walau bagaimanapun, cabaran, risiko dan halangan dapat diatasi apabila usahawan wanita mempunyai kecekapan dalam menguruskan perniagaan. Pengaruh kecekapan keusahawanan terhadap kelebihan daya saing dan kesan kelebihan daya saing terhadap prestasi perniagaan mikro tidak formal yang dimiliki dan diuruskan oleh usahawan mikro dapat melahirkan usahawan wanita yang kompeten. Kompetensi dalam komitmen, konseptual, pengorganisasian dan pengiktirafan peluang menurut Noor Raihani dan Abdullah (2018) mempunyai pengaruh positif yang signifikan terhadap kelebihan daya saing, dan kelebihan daya saing mempunyai pengaruh positif yang signifikan terhadap prestasi perusahaan mikro yang dimiliki serta diuruskan oleh usahawan mikro wanita di Kelantan.

Kajian Suhail et al. (2019) mengenal pasti pelbagai masalah yang dialami oleh usahawan wanita kotej di Oman untuk melancarkan dan mengembangkan perusahaan. Usahawan wanita ini melangkaui peranan keluarga tradisional mereka dengan alasan bagi memantapkan diri dalam masyarakat. Hasilnya mereka mencapai kejayaan walau pun terdapat halangan seperti akses kepada kerajaan untuk keperluan perniagaan semasa, akses kepada pembekal khusus untuk terus mendahului persaingan dan kos bahan mentah yang 
tinggi merupakan masalah yang penting, sementara masalah yang berorientasikan pemasaran tidak begitu membimbangkan. Di Filipina, menurut Aquino (2017) usahawan wanita yang sedang membangun memanfaat media baharu dalam mempermudahkan pelaksanaan portfolio hasil termasuklah persekitaran perniagaan, kewangan, akses pasaran dan produktiviti. Selari dengan Tomos dan Thurairaj (2019), teknologi baharu memudahkan usahawan wanita untuk mengakses latihan dan pendidikan untuk meningkatkan pengetahuan dalam perniagaan. Pengusaha wanita di Singapura pula menurut Carranza et al. (2018) cenderung menggunakan modal peribadi, keluarga dan rakan daripada membuat pinjaman dari institusi kewangan untuk memulakan perniagaan. Tambah Tomos et al. (2020) kejayaan usahawan wanita dalam perniagaan dianggap kompleks merentas-negara kerana melibatkan pelbagai faktor penting misalnya budaya. Pelbagai jenis dan dimensi budaya menunjukkan kesan budaya dan kepentingan gender untuk mentafsir kejayaan usahawan wanita. Menurut Win (2020) pula, usahawan wanita Myanmar yang kreatif, fleksibel dan mengikut orientasi pasaran akan menghasilkan inovasi produk dan inovasi proses dalam perniagaan. Ini menunjukkan walaupun sesetengah golongan wanita memiliki tahap pendidikan rendah, jika diberi peluang untuk berdikari dan bantuan promosi produk kraftangan tradisional yang dihasilkan di rumah dapat memperkasakan golongan wanita dan membantu meningkatkan pendapatan (Neelofer at al. 2019). Tambah Bayisenge et al. (2020) sumbangan wanita dalam pembangunan ekonomi dapat meningkatkan peluang pekerjaan walau pun hanya menjalankan industri kecil. Sumbangan kecil memberi impak dan kontribusi kepada pertumbuhan ekonomi khususnya ekonomi keluarga, ekonomi tempatan dan juga ekonomi negara. Pendayaupayaan wanita merupakan pemangkin kepada penciptaan kerjaya dan pekerjaan, inovasi, transformasi dan sumbangan yang ketara kepada ekonomi sekitarnya (Nor Hanim et al. 2021).

Dari sudut teori pula, kajian mengaplikasi pendekatan Feminis Dunia Ketiga bagi menghuraikan pembentukan usahawan wanita. Berdasarkan pendekatan ini, wanita dalam masyarakat Timur kuat dipengaruhi oleh budaya dan agama yang mencorakkan peranan tertentu yang perlu dimainkan oleh wanita. Bagi Akter, Rahman dan Radicic (2019), usahawan wanita menyumbang kepada pembangunan sosial dan eknomi, peranan sosial dan budaya, yang mana PKS, keusahawanan dan pengantarabangsaan adalah berhubungan secara signifikan berdasarkan teori feminisme. Walaupun pemodenan telah mengubah perspektif baru peranan wanita Timur, faktor keagamaan dan kebudayaan menjadi benteng pendidikan wanita. Ia melibatkan elemen kesetiaan, tanggungjawab, nilai hidup, peranan, fungsi dan tugas membina yang perlu dipertahankan oleh wanita dalam masyarakat moden. Oleh itu, keusahawanan dapat memberi kuasa kepada wanita tetapi sederhana dan perlahan (Ojediran \& Anderson 2020). Pemodenan tidak bermakna membuang semua tradisi hidup dan mengambil apa sahaja yang dianggap moden oleh masyarakat Barat. Wanita di Timur tidak perlu ekstrem dan mengikut pengaruh feminisme Barat. Kebebasan yang diberi kepada wanita tidak bermakna jika bercanggah dengan nilai dan norma masyarakat Timur yang kaya dengan kesopanan dan peradaban. Faktor kebudayaan sosial dan agama amat berpengaruh dalam mencorakkan pergerakan feminisme dan penonjolan isu jantina dalam masyarakat di Dunia Ketiga (Abd. Rahim 1998: 10-11). Berdasarkan huraian dinyatakan teori feminism aliran Dunia Ketiga, setiap individu mempunyai peranan yang berbeza dalam setiap perkara sama ada penglibatan di dalam politik, ekonomi dan sosial. Kajian ini pula memfokuskan kepada usahawan wanita di Pantai Timur Semenanjung Malaysia, iaitu di Kelantan dan Terengganu. Penglibatan wanita dalam keusahawanan ini dilihat lebih menonjol berbanding dengan wanita di negeri-negeri yang lain. Keterlibatan wanita menerusi aktiviti keusahawanan adalah bersesuaian dengan huraian dalam teori feminism iaitu wanita mempunyai pengalaman yang berbeza dengan lelaki. Wanita menurut aliran pemikiran feminism dunia ketiga melihat 'dirinya' sebagai bebas dari pusat sehingga menjadikan dirinya sebagai seorang berfikir secara autonomi (Mansoor 2016). Maksudnya, penglibatan wanita dalam pelbagai sektor ekonomi tidak akan menjejaskan tanggungjawabnya kepada tugas menguruskan rumahtangga. Malah menurut OECD (2020), peranan wanita sangat penting dalam sektor tekstil, pakaian, pemprosesan makanan, barangan isi rumah dan sektor pengeluaran lain. Keperluan ini mengatasi norma dan streotaip gender dalam mengatasi pengagihan semula tanggungjawab menjaga dan menguruskan rumah tangga antara wanita dan lelaki (Ferrant et al. 2014). Keadaan ini berlaku apabila wanita mempunyai tanggungjawab yang berbeza berasaskan kepada sosiobudaya yang terdapat dalam masyarakat. Walaupun penglibatan wanita dalam ruang awam iaitu dalam bidang keusahawanan adalah tinggi dalam kajian ini namun mereka tidak mengetepikan peranan domestik mereka dalam ruang dalaman seperti menguruskan keluarga dan menjaga anak. Oleh yang demikian, mereka mempunyai kebebasan yang mutlak untuk bekerja dalam usaha menaik taraf ekonomi keluarga di samping membantu suami menambah sumber pendapatan dalam keluarga (Wan Abdul Kadir 1998: 6). Aliran feminis ini sesuai menurut Kasseye Bayu (2019) kerana memberi peluang kepada penyertaan ruang awam dan mempertimbangkan wanita di dunia.

Atas pertimbangan tersebut, kajian telah memilih informan kajian yang telah menjalankan perniagaan lebih lima tahun. Bertujuan melihat dorongan yang mempengaruhi pembentukan usahawan wanita. Sementelahan, skop kajian sarjana sebelum ini kurang memberi fokus kepada pembentukan usahawan wanita batik dan songket. Fokus kajian mereka tertumpu kepada cabaran dan halangan dalam perniagaan, permasalahan yang membelenggu usahawan wanita, pemerkasaan 
usahawan wanita, keseimbangan hidup usahawan wanita di luar bandar dan kepentingan inovasi keusahawanan yang dijalankan oleh wanita. Justeru, kajian ini mengambil pendekatan untuk menganalisis pembentukan usahawan batik dan songket wanita dengan melihat kepada empat dorongan iaitu sosialisasi dalam keluarga, kemahiran keluarga, minat dan sumbangan terhadap keluarga.

\section{METODOLOGI KAJIAN}

Bagi menyempurnakan kajian, pendekatan kualitatif digunakan untuk mendapatkan data yang tepat dan jelas menerusi teknik temu bual mendalam dan pemerhatian terhadap informan. Terdapat dua kaedah yang digunakan bagi mengikuti prosedur kajian kualitatif iaitu kajian kes dan kaedah pemerhatian. Namun, dalam konteks kajian ini, kajian kes perlu dilakukan bagi menganalisis dorongan kepada pembentukan usahawan batik dan songket wanita di Malaysia. Kajian kes digunakan untuk memahami sesuatu isu yang kompleks secara terperinci dengan menggunakan sampel yang kecil. Kajian kes juga membantu memahami fenomena yang berlaku kepada usahawan batik dan songket terutamanya apabila sesuatu sempadan dan norma sosial tidak begitu jelas. Manakala kaedah pemerhatian dilakukan untuk mendapatkan gambaran secara menyeluruh daripada informan mengenai situasi yang sedang dikaji.

Pengumpulan data pemerhatian menerusi kaedah pemerhatian tidak ikut serta (participant observation) yang dilakukan ke atas 12 orang informan kajian. Pengkaji tidak terlibat dengan aktiviti keusahawanan batik dan songket namun pengkaji kekal sebagai pemerhati serta diketahui oleh semua informan. Pengkaji menemui informan kajian dan mengemukakan objektif pemerhatian dilakukan serta berinteraksi dengan mereka untuk mendapatkan gambaran secara menyeluruh mengenai dorongan yang menjadi alasan kepada pembentukan usahawan wanita sehingga menjadikan bidang keusahawanan sebagai pekerjaan mereka. Aspek yang diperhatikan ke atas informan kajian adalah bagaimana mereka menguruskan perniagaan, komunikasi yang terjalin di antara usahawan dan pekerja dan komunikasi yang berlaku di antara usahawan wanita dan pelanggan.

Lokasi kajian melibatkan dua negeri iaitu Kelantan dan Terengganu di Pantai Timur, Semenanjung Malaysia. Lokasi yang dipilih berdasarkan pertimbangan bahawa golongan wanita di Malaysia khususnya di Kelantan dan Terengganu terkenal dengan budaya niaga yang tinggi dan pewarisan perniagaan keluarga (Nor Aini 2010; Mohd Nor Hakimin \& Mohd Rafi 2010).

Sampel dipilih menerusi pensampelan bertujuan, berdasarkan kriteria yang menjadi syarat pemilihan kajian. Antara ciri sampel yang dipilih adalah mereka mempunyai kilang atau bengkel mengeluarkan produk sendiri, mempunyai premis perniagaan sendiri (mereka berdaftar dengan Perbadanan Kraftangan Malaysia) dan menjalankan perusahaan batik dan songket lima tahun dan ke atas. Selain itu, sampel juga dipilih melalui pensampelan snowball iaitu pengkaji mengenal pasti usahawan wanita yang bersetuju untuk ditemu bual dan meminta mereka menamakan usahawan wanita yang lain yang juga mengusahakan perniagaan batik dan songket kepada pengkaji.

Sampel terdiri daripada 12 orang usahawan batik dan songket wanita, di mana enam orang di Kelantan dan enam orang di Terengganu. Menurut Othman (2009), dalam kajian kualitatif saiz informan kajian tidak dapat ditentukan dari awal kajian seperti dalam kajian kuantitatif. Pemilihan informan kajian dan analisis data adalah berterusan sehingga mencapai titik tepu. Ketepuan data berlaku apabila tidak ada elemen baharu yang ditemui dan penambahan informasi baharu tidak lagi diperlukan, kerana tidak mengubah pemahaman mengenai fenomena yang diteliti (Nascimento et al. 2018; Guest et al. 2020). Oleh itu, bilangan informan kajian seramai 12 orang dianggap sudah mencukupi apabila informan kajian yang terakhir memberikan jawapan yang berulang seperti informan kajian sebelumnya. Keadaan ini dinamakan sebagai ketepuan data yang menunjukkan jumlah informan kajian adalah sudah mencukupi.

Hasil temu bual dianalisis menerusi analisis tematik. Analisis data secara tematik digunakan untuk menganalisis dorongan pembentukan usahawan batik dan songket wanita. Terdapat enam fasa prosedur menganalisis data secara tematik yang diadaptasi daripada Marshall dan Rossman (1999) iaitu, (1) menyusun atur data, (2) menjana kategori, tema dan pola, (3) mengekod data, (4) menguji kefahaman yang timbul, (5) mencari penerangan alternatif dan (6) menulis laporan. Terdapat empat tema utama dan 11 sub-tema dalam konteks pembentukan usahawan batik dan songket wanita di Pantai Timur. Tema-tema tersebut adalah sosialisasi dalam keluarga (sub-tema; asuhan, pembelajaran sosial, pengetahuan dan kemahiran dan latihan), kemahiran keluarga (sub-tema; turun-temurun, latar belakang keluarga dan inspirasi), minat (sub-tema; keutamaan peribadi dan peluang yang dimiliki) dan sumbangan terhadap keluarga (sub-tema; taraf hidup dan perbelanjaan keluarga). Sementara maklumat yang diperolehi melalui pemerhatian terhadap usahawan batik dan songket wanita dianalisis melalui nota lapangan, gambar visual dan rakaman suara.

\section{PENEMUAN KAJIAN}

Informan yang menjadi subjek dalam kajian ini berumur di antara 27 hingga 56 tahun terdiri daripada enam orang usahawan wanita mengusahakan batik di Kelantan manakala enam orang usahawan wanita mengusahakan songket di Terengganu. Tahap pendidikan informan menunjukkan dua orang berkelulusan Ijazah, seorang berkelulusan Diploma, berkelulusan STPM, enam orang berkelulusan SPM dan dua orang berkelulusan PMR. 
Semua informan telah memulakan perniagaan batik dan songket di antara umur tujuh hingga 37 tahun. Daripada 12 orang informan tersebut, lima orang merupakan pengusaha songket dan selebihnya adalah pengusaha batik. Dalam konteks asal usul perniagaan, terdapat informan yang ditemui meneruskan perniagaan warisan daripada generasi sebelumnya iaitu, daripada ibu dan bapa mentua mereka. Tujuh orang merupakan pewaris perniagaan daripada ibu manakala dua orang mewarisi perniagaan daripada bapa mentua.

Penemuan kajian menunjukkan terdapat empat dorongan yang menjadi alasan kepada pembentukan usahawan wanita di Pantai Timur, Semenanjung Malaysia iaitu (1) sosialisasi dalam keluarga, (2) kemahiran keluarga, (3) minat dan, (4) sumbangan terhadap keluarga. Berdasarkan dorongan tersebut, terdapat enam orang informan yang ditemui menyatakan dorongan sosialisasi dalam keluarga telah berjaya membentuk dirinya menjadi seorang usahawan batik dan songket wanita di Malaysia. Selain itu, dorongan kemahiran keluarga menjadi alasan kepada empat orang informan yang menyebabkan mereka berkecimpung dalam perniagaan berasaskan batik dan songket manakala enam orang informan menyatakan dorongan minat menjadi sebab kepada pembentukan diri mereka ke arah keusahawanan. Selain itu, dorongan sumbangan terhadap keluarga juga menjadi alasan kepada empat orang informan terhadap kewujudan mereka sebagai usahawan batik dan songket wanita.

\section{SOSIALISASI DALAM KELUARGA}

Dalam konteks kajian keusahawanan batik dan songket, proses sosialisasi oleh keluarga misalnya dari segi didikan dan tunjuk ajar merupakan pencetus utama kepada pembentukan usahawan wanita di Malaysia. Kajian mendapati terdapat empat sub-tema sosialisasi dalam keluarga iaitu asuhan; pembelajaran sosial; pengetahuan ilmu keusahawanan; dan kemahiran latihan dalam perniagaan (Jadual 1).

JADUAL 1. Dorongan sosialisasi dalam keluarga

\begin{tabular}{ll}
\hline Tema & Sub-tema \\
\hline Sosialisasi & Asuhan \\
dalam keluarga & Pembelajaran sosial \\
& Pengetahuan ilmu keusahawanan \\
& Kemahiran dan latihan dalam perniagaan \\
\hline
\end{tabular}

Sumber: Kajian lapangan (2015)

Asuhan Asuhan yang diterima daripada keluarga yang telah berniaga menonjolkan minat terhadap aktiviti perniagaan batik dan songket, menerusi tunjuk ajar dan dorongan mendalam tentang selok-belok perniagaan sebelum mengambil alih perniagaan tersebut.
Aspek asuhan adalah ajaran yang diberi oleh orang tua tentang dunia perniagaan sejak kecil sehingga mampu menerbitkan minat dalam diri. Selain itu, peranan ganjaran yang akan diterima sekiranya membantu ibu atau bapa dalam perniagaan juga menimbulkan minat individu dalam keusahawanan. Situasi ini menunjukkan anak yang didedahkan dengan perniagaan di awal usia lebih cenderung mengikut jejak langkah ibu atau bapa mereka dengan menjadi seorang usahawan. Tambahan pula, bidang perniagaan menjanjikan keuntungan yang lumayan sehingga menarik minat wanita untuk menceburinya. Menurut Puan Yah yang telah mengusahakan perniagaan songket selama 30 tahun sejak berumur 12 tahun menyatakan bahawa:

Dari kecik lagi mok train (ajar) kak. Sejak umo 12 tahun lagi. Sapa loni kak ingat lagi gapo mok bagitau dulu. Mok tanya kak, "Mu nok duit dok? Kalau mu nok duit, kena tolong mok niaga (sambil fikir dalam kepala)”. Kalau tak tolong tak boleh duit, kak pun tolonglaa mok niaga. Sambil tolong mok niaga, sambil mok bagitahu cara-cara nak niaga, nak urus perniagaan dengan baik. Kak ambil sebagai panduan lah tu, apa yang mok kak bagitahu dulu tu. [Sumber: Kajian lapangan pada 2015 bersama Puan Yah].

Sebahagian informan yang menyatakan minat ke atas keusahawanan timbul daripada ahli keluarga yang pernah berniaga. Ini adalah kerana wanita yang berasal daripada keluarga yang berniaga sememangnya mendapat asuhan daripada pengasas perniagaan keluarganya. Pengasas perniagaan merupakan orang yang mula-mula menubuhkan perniagaan dalam keluarga. Mereka perlu memastikan pengganti yang bakal meneruskan legasi perniagaan yang telah dimulakan mempunyai pengalaman yang mencukupi sebelum mengambil alih perniagaan. Oleh itu, asuhan yang diberikan dengan berterusan adalah bertujuan untuk memberi pendedahan dan cara untuk menguruskan sesebuah perniagaan. Pendedahan secara berterusan penting dalam menyediakan bakal pengganti yang mempunyai pengetahuan dan kemahiran yang mantap bagi menguruskan arah tuju perniagaan keluarga pada masa depan.

Pembelajaran Sosial Pembelajaran sosial merupakan satu proses pemerhatian anak yang melihat si ibu melakukan aktiviti perniagaan secara langsung setiap hari. Pemerhatian tersebut berlaku ketika anak-anak masih remaja dan proses ini memberi peluang kepada mereka untuk menjadi usahawan wanita seperti ibu mereka. Pada masa yang sama juga, anak-anak boleh bertanya perkara yang mereka tidak faham sepanjang pemerhatian tersebut berlaku. Ia bermula dengan minat dan cita-cita untuk menjadi seperti ibu mereka demi meneruskan kelangsungan perusahaan warisan keluarga. Proses pemerhatian awal oleh anak didapati memberi kesan yang besar terhadap perkembangan keusahawanan dalam diri wanita. Misalnya, pembelajaran sosial yang diterima oleh 
Puan Idah yang mewarisi perusahaan warisan songket keluarga daripada ibu menyatakan bahawa:

Saya selalu perhati macam mana ibu menguruskan perniagaan songketnya sejak usia remaja saya. Kadangkala saya tanya pada ibu apa yang saya tidak faham tentang aspek pengurusan perniagaan. Ini saya anggap sebagai proses pembelajaran sosial yang berlaku secara langsung. [Sumber: Kajian lapangan pada 2015 bersama Puan Idah].

Proses ini berlaku melalui pemerhatian dalam jangka waktu yang lama dan sentiasa berulang-ulang sehingga menjadi perkara rutin kepada anak-anak yang memerhatikannya. Oleh yang demikian, apabila meningkat dewasa mereka turut menunjukkan minat yang sama seperti ibu dengan mengusahakan perniagaan yang sama.

Pengetahuan dan Ilmu Keusahawanan B i d a n g keusahawanan merupakan satu bidang yang mencabar dan memerlukan pengetahuan yang tinggi bagi menghadapi risiko untung rugi yang tidak dijangka. Ilmu pengetahuan luas sangat diperlukan iaitu meliputi perancangan masa depan perniagaan bagi meningkatkan jumlah pendapatan yang lebih tinggi pada masa hadapan. Bagi mereka yang sememangnya dilahirkan dalam keluarga yang telah sedia menjalankan perniagaan pula, ini merupakan satu kelebihan. Seperti yang dinyatakan oleh Puan Zita yang merupakan pengusaha batik terkenal di bandar Kota Bharu:

Lepas tamat belajar, saya bekerja dengan emak terlebih dahulu sebab nak tahu macam mana nak urus perniagaan. Tapi selepas mak tidak dapat handle perniagaan dia sebab dia sakit, saya tidak la rasa kekok nak ambil alih perniagaan warisan keluarga dari emak. [Sumber: Kajian lapangan pada 2015 bersama Puan Zita].

Pengetahuan yang sedia ada mengenai perniagaan sebelum terlibat secara sepenuh masa dapat dimanfaatkan setelah mengambil alih perniagaan keluarga daripada pengusaha asal yang menjadi punca penglibatan dalam industri kraf batik.

\section{Kemahiran dan Latihan Perniagaan}

W a n i t a yang terlebih dahulu bekerja dengan orang lain mampu menguruskan perniagaan dengan cekap kerana telah mempunyai kemahiran dan latihan. Kemahiran yang dimiliki memberi keyakinan kepada bakal usahawan wanita untuk memiliki perniagaan mereka sendiri. Di samping itu, jaringan perniagaan yang dibina di antara usahawan yang telah lama terlibat dan terkenal dalam keusahawanan yang berasaskan batik dan songket dapat diperkukuhkan. Elemen kemahiran dan latihan perniagaan ini ditonjolkan oleh Puan Dah iaitu:

Kak kerja di kedai jual batik dale (dalam) tiga tahun seblum ni. Ado minat nok nego ni. Keluarga suami pulok ado perniagaan hok jual batik tapi gak suami tak minat. Ayah tuo cayo ko kak untuk urus perniagaan dio. Oleh sebab kak pernah kijo kat kedai jual batik dulu, bulehla kak ambik alih kedai ayah tua kak ni. [Sumber: Kajian lapangan pada 2015 bersama Puan Dah].

Elemen kemahiran dan latihan didapati mempunyai kesan yang besar ke atas keputusan yang diambil oleh wanita apabila ingin melibatkan diri dalam perniagaan batik dan songket. Bidang keusahawanan memerlukan kemahiran dan latihan dari segi pemasaran dan perancangan masa depan supaya perniagaan yang diusahakan dapat bersaing dengan perniagaan yang lain. Perniagaan yang berasaskan batik dan songket merupakan cabang perniagaan yang diminati ramai usahawan wanita di Kelantan dan Terengganu disebabkan mempunyai prospek pasaran yang luas. Kesan daripada kemahiran dan latihan yang dimiliki dapat dijelaskan lagi melalui analisis Mohd. Shariff et al. (2004) yang menyatakan sesetengah individu yang berada dalam kumpulan atau golongan yang kaya dengan budaya keusahawanan, proses sosialisasi yang berterusan dan disokong dengan bantuan dalam bentuk material dan moral berterusan sama ada secara langsung dan tidak langsung juga boleh mendorong seseorang untuk menceburkan diri dalam bidang keusahawanan. Ini menunjukkan ia dapat dipelajari dan dipupuk dalam kalangan ahli keluarga yang lain tanpa mengira peringkat umur.

\section{KEMAHIRAN KELUARGA}

Kemahiran keluarga dalam kajian ini ialah kemahiran berniaga yang ada dan diwarisi daripada keluarga sama ada mewarisi perniagaan daripada ibu, bapa, datuk ataupun nenek. Kebanyakan keluarga yang menjalankan perniagaan memindahkan kemahiran berniaga melalui pewaris perniagaan dalam keluarga merekayang bertujuan untuk mengekalkan perniagaan yang telah diusahakan. Pewarisan kemahiran berniaga dalam sesebuah keluarga dapat bertahan sehingga beberapa generasi selagi terdapat pewaris yang mengusahakan perniagaan tersebut. Oleh yang demikian, individu yang berasal daripada keluarga berniaga berpotensi untuk menjadi usahawan disebabkan oleh latar belakang mereka yang mempunyai kemahiran berniaga. Oleh itu, pembentukan usahawan batik dan songket boleh dijelaskan melalui aspek turun-temurun, latar belakang keluarga yang terlebih dahulu menceburi dunia keusahawanan dan sumber inspirasi daripada ahli keluarga yang lain (Jadual 2).

JADUAL 2. Dorongan kemahiran keluarga

\begin{tabular}{ll}
\hline Tema & Sub-tema \\
\hline Kemahiran keluarga & Turun-temurun \\
& Latar belakang keluarga \\
& Inspirasi \\
\hline
\end{tabular}

Sumber: Kajian lapangan (2015) 
Turun-Temurun Turun-temurun merupakan sistem perniagaan keluarga yang telah dimulakan oleh generasi awal dan diwarisi oleh generasi kedua sehingga generasi yang seterusnya. Mereka yang terlibat dalam perniagaan keluarga ini akan berusaha meneruskan kesinambungan perniagaan tersebut bagi menghargai jasa pengasas perniagaan yang terdahulu. Oleh sebab itu, mereka yang terdiri dari keluarga berniaga memiliki sedikit kelebihan berbanding dengan mereka yang bukan berasal daripada keluarga berniaga kerana memiliki perniagaan warisan keluarga yang sudah kukuh sejak sekian lama. Temu bual terhadap Puan Non yang memiliki kemahiran berniaga daripada keluarga sejak turun-temurun menyatakan bahawa:

Saya pandai berniaga sebab dapat dari mak. Mak dari dulu mula berniaga. Kiranya saya nii generasi kedua lah yang berniaga dalam keluarga selepas mak. [Sumber: Kajian lapangan pada 2015 bersama Puan Non].

Pewarisan kemahiran keusahawanan daripada ibu yang telah bertapak sejak sekian lama mempengaruhi informan menjalankan aktiviti perusahaan songket. Tempoh perniagaan keluarga yang telah lama beroperasi turut berperanan penting terhadap setiap keputusan yang diambil oleh individu yang bakal mewarisi perniagaan. Perniagaan yang diusahakan sejak turun-temurun wajar dipertahankan supaya pengganti yang mengambil alih dapat mengembangkan perniagaan tersebut dengan lebih jauh lagi. Pengganti yang akan mengambil alih pula terdiri dalam kalangan ahli keluarga yang terdekat di dalam keluarga seperti anak perempuan ataupun anak lelaki kepada pengasas perniagaan. Dengan adanya pengganti, maka perniagaan yang telah diusahakan sejak puluhan tahun lalu dapat bertahan dengan lebih lama.

Latar Belakang Keluarga Anak yang dibesarkan dalam lingkungan keluarga yang menjalankan perniagaan lebih berminat untuk menceburi bidang pekerjaan yang sama. Situasi ini berlaku apabila mereka telah melihat bagaimana perniagaan tersebut diusahakan sejak dari kecil. Di samping itu, sesetengah ibu atau bapa yang berniaga pula akan membawa anak-anak mereka ke tempat mereka berniaga selepas waktu persekolahan. Apabila proses ini berlaku secara berulang-ulang, anak-anak yang selalu melihat ibu atau bapa mereka mengusahakan perniagaan akan mempengaruhi keputusan mereka untuk menjadi usahawan bagi meneruskan perniagaan keluarga. Penemuan tentang latar belakang keluarga dapat diteliti ke atas informan kajian Puan Idah yang menguruskan perniagaan warisan keluarga berasaskan kepada penjualan dan perusahaan songket yang terletak di tengah bandar Kuala Terengganu sejak 2008. Katanya:

20 tahun doh perniagaan songket ni dok jalan lepah ditubuh oleh mak saya. Saya nok tengok ado perniagaan keluarga ni berterusan selalu. Kalu saya tok ambil alih, sapo lagi hok boleh harap sebabnyo saya ni anok tunggal dale (dalam) keluarga. [Sumber: Kajian lapangan pada 2015 bersama Puan Idah].

Kajian ini mendapati wanita yang berasal daripada latar belakang keluarga yang menjalankan perniagaan menjadi dorongan terpenting kepada penglibatan mereka dalam perniagaan. Ia terjadi apabila mereka sering melihat perniagaan yang dijalankan pada setiap hari berlaku dalam keluarga. Situasi ini memberi peluang kepada mereka untuk mengambil alih perniagaan yang telah diusahakan oleh keluarga mereka seterusnya melanjutkan perkembangan perniagaan keluarga.

Inspirasi Pembentukan usahawan wanita juga boleh berlaku melalui sumber inspirasi daripada kejayaan ahli keluarga lain yang terlebih dahulu menceburi aktiviti keusahawanan. Dengan erti kata lain, mereka menjadikan ahli keluarga yang telah berjaya sebagai idola sebelum membuka perniagaan sendiri. Inspirasi dan kekaguman terhadap kejayaan tersebut menjadi pendorong kepada diri mereka dalam menubuhkan sesebuah perniagaan. Tambahan pula, aktiviti jual beli mampu memberi banyak keuntungan kepada mereka. Kejayaan ahli keluarga lain yang telah mempunyai perniagaan sendiri turut menjadi inspirasi kepada wanita untuk menjadi seorang usahawan. Perniagaan ahli keluarga yang berkembang dengan maju dikatakan menarik minat wanita untuk menjadikan perniagaan sebagai sumber rezeki. Inspirasi daripada kejayaan ahli keluarga yang lain dapat diteliti dalam kes Puan Ta. Menurut Puan Ta:

Mulanya kak hanya bantu abang je sebab abang ada kedai jual barang kemas dua buah. Dia mintak kak tolong jaga dulu. Time cuti sekolah, kak gi laa tolong dia jaga sebab masa tu orang ramai mari beli. Lama lepas tu rasa seronok pulak berniaga ni. Boleh pitis (duit) banyak selalu (ketawa). Jadi inspirasi dari kejayaan abang, kak bukok kedai sendiri la. Ni pun kongsi dengan kakak. Gilir-gilir la mari jaga kedai ni. [Sumber: Kajian lapangan pada 2015 bersama Puan Ta].

Pada permulaannya, informan hanya membantu ahli keluarga yang berniaga di bandar Kota Bharu selepas menamatkan pengajian peringkat ijazah. Lamakelamaan timbul minat untuk menjadi usahawan seperti ahli keluarganya setelah melihat bidang perniagaan ini mendatangkan keuntungan dengan begitu cepat.

\section{MINAT}

Minat yang dimaksudkan dalam kajian ini adalah minat untuk berniaga. Mereka mempunyai kecenderungan tinggi terhadap aktiviti keusahawanan yang berpotensi menggapai cita-cita mereka sebagai usahawan yang berjaya. Minat juga dapat mencungkil sifat yakin dengan keupayaan diri untuk mengusahakan sesebuah 
perniagaan. Huraian mengenai elemen minat ke atas dorongan pembentukan usahawan wanita ini dibincangkan berasaskan dua aspek iaitu, keutamaan peribadi dan peluang yang dimiliki (Jadual 3).

JADUAL 3. Dorongan minat

\begin{tabular}{ll}
\hline Tema & Sub-tema \\
\hline Minat & Keutamaan peribadi \\
& Peluang \\
\hline
\end{tabular}

Sumber: Kajian lapangan (2015)

\section{Keutamaan Peribadi}

Keutamaan peribadi ialah minat yang terpendam dalam diri wanita sejak sekian lama untuk menjadi usahawan wanita. Minat yang ada dalam diri juga wujud sama ada melalui rangsangan daripada kejayaan rakan-rakan mereka yang telah berjaya sebagai usahawan. Namun, ada juga golongan wanita yang menganggap bidang ini mudah menjana keuntungan berbanding dengan bekerja makan gaji. Keuntungan yang tinggi diperolehi menerusi perniagaan merupakan alasan utama wanita ingin menjadi usahawan wanita. Terdapat wanita yang mengambil keputusan melepaskan jawatan di sektor kerajaan semata-mata untuk mengejar keutamaan peribadi mereka. Tindakan melepaskan jawatan bergaji tersebut merupakan satu contoh yang menggambarkan kecenderungan ataupun minat wanita lebih tinggi ke arah keusahawanan. Informan menyatakan:

Saye buat keputuse (keputusan) tepat nok bereti kijo (kerja) cikgu dulu. Bidang perniagaan ni banyok beri keuntungan. Takdok pun ore lain hok pengaruhi saye hok buat saye ambik keputusan gini. [Sumber: Kajian lapangan pada 2015 bersama Puan Na].

Dorongan minat menjadi elemen terpenting kepada pencapaian matlamat seseorang usahawan. Walaupun kebanyakan usahawan wanita yang mengusahakan perniagaan batik dan songket memiliki taraf pendidikan sehingga SPM, namun elemen minat tertanam dengan kukuh dalam diri mereka. Minat yang tinggi dalam bidang ini mendorong mereka menjadikan bidang keusahawanan sebagai lubuk mencari rezeki. Peluang yang terbentang luas membolehkan wanita dapat mencungkil sifat yakin dengan keupayaan diri untuk mengusahakan perniagaan. Oleh itu, mereka perlu bersedia dalam menghadapi pelbagai halangan bagi merebut peluang yang sama rata dengan golongan lelaki. $\begin{array}{llr}\text { Peluang Yang Dimiliki } & \text { Peluang yang } \\ \text { dimiliki dalam konteks kajian ini adalah peluang }\end{array}$ mewarisi perniagaan keluarga, peluang meningkat pendapatan keluarga dan peluang menyertai aktiviti keusahawanan yang dianjurkan oleh pelbagai pihak. Wanita yang terlebih dahulu bekerja dengan orang lain untuk mendapatkan kemahiran dan latihan dalam perniagaan sebelum mewarisi perniagaan keluarga dianggap sebagai penggerak yang boleh memupuk minat usahawan dalam keusahawanan. Situasi yang dihadapi oleh informan mengenai peluang yang dimiliki ialah:

Saya sokmo (selalu) rebut peluang hok ada untuk kebaikan perniagaan batik saya ni. Gapo (apa) hok KRAFTANGAN anjur, sokmo ikut. Saya pun jual batik ni secara online jugok. Untung hok saya buleh, saya labur pulok buat rolling nok tingkatkan pendapatan dale (dalam) perniagaan. [Sumber: Kajian lapangan pada 2015 bersama Puan Sham].

Kebanyakan wanita beranggapan bidang keusahawanan memberi pendapatan yang tinggi berbanding dengan pendapatan secara bulanan. Pendapatan tinggi yang diperolehi menerusi aktiviti perniagaan yang dijalankan mendorong wanita untuk menjana pendapatan tambahan seperti kekerapan menyertai pelbagai pameran di seluruh negara yang dianjurkan oleh KRAFTANGAN dan memasarkan produk batik secara atas talian. Strategi ini secara langsung memberi keuntungan kepada perniagaan kerana produk batik itu sendiri sentiasa digemari oleh pelbagai peringkat umur. Keuntungan yang diperolehi melalui perniagaan adalah lumayan yang boleh meningkatkan pendapatan perniagaan. Keadaan ini memberi kelebihan kepada pengusaha tekstil dalam memberi sumbangan terhadap keluarga dari segi kualiti hidup yang dimiliki. Pemerhatian pengkaji ke atas peserta kajian yang mengusahakan perusahaan batik dan songket menunjukkan mereka masih lagi berniaga walaupun telah berada dalam usia warga emas. Mereka menyatakan keperluan untuk terus bekerja bagi mengukuhkan kedudukan ekonomi keluarga kerana suami sudah tidak mampu bekerja atas faktor kesihatan. Pada masa yang sama, terdapat usahawan wanita mempunyai tanggungan dalam keluarga sehingga memerlukan mereka untuk mencari sumber pendapatan tambahan.

\section{SUMBANGAN TERHADAP KELUARGA}

Sumbangan dilihat dalam konteks menambah pendapatan keluarga dan mengubah nasib keluarga yang menjadikan mereka perlu keluar bekerja bagi meningkatkan jumlah pendapatan keluarga serta mengubah nasib keluarga mereka dengan lebih baik. Keputusan wanita keluar bekerja bukan sahaja dibuat untuk membantu suami menambah pendapatan malah memenuhi keinginan wanita mempunyai pendapatan sendiri. Analisis yang diperolehi menunjukkan sumbangan terhadap keluarga menjadi punca informan terlibat dalam perniagaan batik dan songket sebagai sumbangan kecil mereka terhadap keluarga yang dilihat menerusi aspek taraf hidup dan perbelanjaan keluarga (Jadual 4). 
JADUAL 4. Dorongan sumbangan terhadap keluarga

\begin{tabular}{ll}
\hline Tema & Sub-tema \\
\hline Sumbangan kepada keluarga & Taraf hidup \\
& Perbelanjaan keluarga \\
\hline
\end{tabular}

Sumber: Kajian lapangan (2015)

Taraf Hidup Taraf hidup merupakan alasan penting dalam konteks sumbangan terhadap keluarga dalam kalangan usahawan wanita yang menceburi perniagaan bermotifkan batik dan songket. Motif penglibatan mereka dalam perniagaan berpunca daripada taraf pendidikan yang rendah serta pendapatan bulanan yang tidak mencukupi bagi menampung perbelanjaan dalam keluarga. Kekangan sedemikian menjadi pendorong kepada wanita untuk berjinak-jinak dalam aktiviti keusahawanan. Hal ini kerana pendapatan suami sahaja tidak mencukupi untuk menyara keluarga. Bagi keluarga yang mempunyai bilangan anak yang ramai, sumber ekonomi keluarga yang tidak mencukupi menjadi tekanan kepada wanita untuk mencari pendapatan sampingan. Bidang keusahawanan dapat membuka peluang kepada wanita untuk mendapatkan pendapatan sampingan sebagai pendapatan sokongan kepada suami. Informan menyatakan seperti berikut:

Suami hanyo kijo (kerja) sebagai tukang rumah. Pastu gaji hok buleh pun sikit. Tak cukup. Saya dok mikir saye keno kijo ni. Nego (niaga) sebab nok baikki taraf hidup keluarga saya. Sene (senang) sikit anak-anak dapat pendidikan sempurna. [Kajian lapangan pada 2015 bersama Puan Mas].

Sebelum memiliki perniagaan yang beliau usahakan sekarang, informan tidak bekerja kerana membesarkan anak-anak seramai empat orang. Suami beliau seorang tukang rumah dan pendapatan yang diperolehi tidak mencukupi untuk meningkatkan taraf hidup mereka sekeluarga bagi memberi pendidikan yang sempurna kepada anak-anak. Oleh yang demikian, informan membuat keputusan untuk berniaga kerana pendapatan suami sebagai tukang rumah tidak mencukupi untuk perbelanjaan keluarga mereka. Walaupun memiliki pendidikan yang rendah, namun sifat tekad membantu suami menjadi pendorong yang kuat untuk berdikari dengan bekerja di luar rumah bagi mendapatkan taraf hidup yang lebih baik. Selain daripada mengubah taraf hidup keluarga, pendidikan anak-anak juga menjadi keutamaan ibu bapa supaya anak-anak mendapat pendidikan yang sempurna. Oleh itu, dengan memberikan pendidikan yang terbaik kepada anak-anak maka taraf hidup keluarga secara keseluruhannya dapat diperbaikki.

Perbelanjaan Keluarga Perbelanjaan keluarga merupakan perbelanjaan dalam isi rumah di mana pendapatan sedia ada tidak mencukupi bagi kegunaan keluarga. Bagi keluarga yang mempunyai tanggungan yang ramai pula, pendapatan suami hanyalah sekadar cukup-cukup makan sahaja. Keadaan ini membuka peluang kepada si isteri untuk terlibat dalam dunia keusahawanan sebagai sumber pendapatan kedua selain suami bagi meningkatkan pendapatan dalam konteks perbelanjaan keluarga. Ketidaktentuan pendapatan yang diperoleh suami memaksa wanita bekerja sendiri dengan mengusahakan perniagaan. Manakala faktor bilangan anak yang ramai juga mencetuskan idea kepada wanita untuk berniaga. Melalui aktiviti perniagaan yang dijalankan, perbelanjaan keluarga dapat dipenuhi tanpa mengharapkan kepada pendapatan suami sepenuhnya. Penerangan mengenai aspek perbelanjaan keluarga diteliti ke atas Puan Tom. Untuk menampung perbelanjaan keluarga yang semakin meningkat, beliau mengusahakan perniagaan berasaskan songket yang merupakan perniagaan warisan keluarga. Puan Tom berkata:

Saya ado tujuh ore (orang) anok. Suami kijo (kerja) nelayan sepenuh masa dengan pendapatan tok tentu. Nasib baikla saya ado warisi perusahaan songket dari mok. Jadi adola duit nok tampung blanjo keluarga serba sikit maso tu. [Sumber: Kajian lapangan pada 2015 bersama Puan Tom].

Sumbangan informan terhadap keluarga dapat diberikan menerusi perbelanjaan keluarga. Informan menyatakan pekerjaan suami sebagai nelayan tidak mencukupi untuk menyara keluarga. Oleh itu, melalui perniagaan tersebut, informan kajian mampu menyumbang kepada keluarganya dalam konteks perbelanjaan keluarga.

\section{PERBINCANGAN}

Proses pembangunan yang rancak menuntut wanita bersaing dengan golongan lelaki khususnya dalam sektor pekerjaan menyebabkan wanita mempunyai hak dan peranan yang sama dengan lelaki. Namun begitu, dalam perkara tertentu golongan lelaki tetap mempunyai peranan yang lebih penting berbanding wanita. Contohnya, dalam keluarga dan rumah tangga, suami tetap memainkan peranan penting sebagai pemimpin ataupun ketua (Zarina \& Zuraida 2016: 80). Keadaan ini menunjukkan terdapat perbezaan peranan di antara wanita dan lelaki dalam pelbagai konteks. Perbezaan peranan di antara wanita dan lelaki menyebabkan wujudnya kuasa wanita yang mendominasi menerusi sektor pekerjaan tertentu di mana dalam konteks kajian ini adalah aktiviti keusahawanan batik dan songket. Situasi tersebut menggalakkan peningkatan usahawan wanita untuk menambah pendapatan dalam keluarga mereka. Walaupun pendapatan daripada aktiviti perniagaan merupakan sumber rezeki namun, elemen minat juga mempunyai peranannya yang tersendiri. 
Minat terhadap perniagaan dan mempunyai keyakinan yang tinggi mengenai potensi aktiviti ekonomi akan memudahkan pengurusan perniagaan. Melalui minat yang mendalam dan pengalaman yang dimiliki, usahawan wanita menganggap sektor keusahawanan dapat menjana pendapatan yang lumayan (Rosman \& Mohd Rosli 2011). Terdapat sesetengah usahawan telah disemai semangat keusahawanan semasa mereka masih lagi kanak-kanak. Kesan pengalaman semasa kanak-kanak seperti bekerja keras, rajin, berdikari dan gigih ini akan memupuk diri mereka supaya lebih cenderung ke arah memperolehi sifat keusahawanan (Sharifah Nazira 2012).

Wanita yang mendominasi aktiviti keusahawanan batik dan songket juga mewujudkan satu kuasa iaitu budaya berniaga yang banyak dilihat di kawasan Pantai Timur Semenanjung Malaysia. Dominasi dalam perniagaan ini terkenal dan dilihat lebih menonjol di Pantai Timur berbanding di negeri-negeri yang lain. Keunikan mereka terserlah apabila ramai golongan wanitanya menceburi dunia perniagaan sebagai salah satu cara untuk mendapat sumber kewangan bagi menstabilkan perbelanjaan keluarga mereka. Walaupun suami mereka bekerja bagi menampung ekonomi di dalam keluarga, namun wanita yang tinggal di Pantai Timur mempunyai semangat yang tinggi dengan menceburi bidang keusahawanan. Dalam kes kajian ini, dominasi wanita dalam perniagaan batik dan songket ditonjolkan melalui perhubungan kuasa lelaki dan wanita. Kuasa wanita yang dimaksudkan adalah sebagai usahawan batik dan songket wanita yang sangat aktif dalam bidang keusahawanan di Kelantan dan Terengganu. Pengaruh budaya niaga yang diwarisi daripada keluarga menyebabkan golongan wanita memonopoli aktiviti perniagaan di dua kawasan tersebut. Keadaan ini menyebabkan kuasa wanita dalam keusahawanan batik dan songket lebih berkuasa berbanding dengan golongan lelaki (Nor Hanim 2018).

Proses sosialisasi juga membolehkan wanita mempelajari kemahiran berniaga melalui tunjuk ajar daripada ibu ataupun bapa. Begitu juga dengan kemahiran berniaga yang dimiliki dalam sesebuah keluarga. Kemahiran berniaga yang telah sedia ada dalam keluarga akan diwarisi secara turun-temurun daripada generasi terdahulu kepada generasi yang baru. Penemuan kajian ini menggambarkan perniagaan warisan keluarga didapati menggalakkan pembentukan usahawan wanita untuk terlibat secara langsung dalam keusahawanan batik dan songket khususnya di Kelantan dan Terengganu. Peratusan yang tinggi usahawan wanita yang mewarisi perniagaan daripada keluarga adalah selari dengan dorongan warisan keluarga yang diperolehi menerusi budaya berniaga yang telah tertanam di dalam diri. Mereka ini telah mempunyai 'tapak' yang kukuh bagi mengembangkan perniagaan yang diwarisi. Dapatan kajian ini seiring dengan kajian Zarina dan Zuraida (2016) yang mendapati latar belakang memainkan peranan dalam menimbulkan minat mereka untuk turut terlibat dalam bidang keusahawanan. Selain itu, sokongan daripada keluarga terdekat juga menjadi pendorong utama mereka.

Bersesuaian dengan teori feminism yang dibincangkan sebelum ini, wanita dapat menyumbang dalam pelbagai bentuk ke arah pembangunan keluarga mereka. Peranan wanita pula tidak terhad dengan peranan di dalam rumah sahaja malah mereka mampu mempelbagaikan peranan sesuai dengan keadaan semasa. Dalam konteks sumbangan terhadap keluarga, bentuk sumbangan yang diberikan wanita adalah melalui aktiviti keusahawanan batik dan songket. Penglibatan wanita dalam aktiviti ini bukan sahaja untuk menyambung perniagaan warisan keluarga, tetapi bagi membantu suami menambah sumber kewangan keluarga. Oleh yang demikian, penglibatan wanita di luar rumah dianggap telah setanding dengan golongan lelaki sebagai sumber pendapatan kedua di dalam keluarga. Anggapan yang mengatakan tugas wanita di rumah dan tugas suami sebagai pencari nafkah pada masa sekarang kurang sesuai dipraktikkan. Ia didorong oleh faktor-faktor penggalak seperti keadaan ekonomi, keupayaan untuk bekerja, potensi upah, keadaan keluarga, peluang-peluang pekerjaan yang ditawarkan dan faktor psikologikal. Semua faktor ini menjadi pendorong kepada golongan wanita untuk keluar bekerja di luar rumah (Noor Rahamah 2009; Sweet 1973).

Selaras dengan hasrat kerajaan untuk mencapai negara maju menjelang tahun 2020, Industri 4.0 atau Revolusi Perindustrian Keempat merupakan cara hidup dan cara bekerja yang berasaskan kepada tiga teknologi iaitu teknologi fizikal, digital dan biologikal. Revolusi ini merentasi sembilan tonggak Industri 4.0, merangkumi simulasi dan realiti maya, integrasi sistem menegak dan melintang, industri internet of things (IoT), keselamatan siber, pengkomputeran awan, pembuatan bahan tambahan, rantaian bekalan, analisis data raya dan robot automasi (Berita Harian, Jun 2017). Mereka seharusnya memanfaatkan setiap peluang dan sentiasa berfikiran kreatif. Aktiviti keusahawanan memerlukan usahawan wanita bergerak dengan pantas dengan menghasilkan rekaan dan corak-corak yang terkini berkaitan produk batik dan songket. Manakala dalam aspek komunikasi, usahawan batik dan songket wanita mesti meningkatkan keupayaan kemahiran berkomunikasi sama ada secara lisan ataupun bertulis. Hal ini kerana industri 4.0 ini memerlukan masyarakat berdiskusi di mana-mana sahaja dan berbeza sebelum meledaknya industri 4.0 apabila masyarakat berkomunikasi secara bersemuka. Oleh itu, usahawan wanita perlu mempersiapkan diri dengan capaian internet melalui peranti elektronik bagi memudahkan komunikasi dengan pelanggan dan jaringan keusahawanan yang lain. Kemunculan industri 4.0 dengan era digital tanpa sempadan ini mampu meningkatkan jumlah usahawan wanita dalam industri kraftangan berasaskan batik dan songket. Keadaan ini secara tidak langsung menunjukkan penguasaan wanita dalam bidang keusahawanan dapat bergerak selari 
dengan perkembangan teknologi dengan hanya di hujung jari.

\section{KESIMPULAN DAN CADANGAN KAJIAN SUSULAN}

Keseluruhan perbincangan menunjukkan dorongan sosialisasi dalam keluarga, kemahiran keluarga, minat dan sumbangan terhadap keluarga, merupakan asas pembentukan usahawan batik dan songket wanita di Malaysia. Kepelbagaian peranan yang dilaksanakan wanita dapat dikembangkan dengan terlibat dalam keusahawanan. Aktiviti keusahawanan di luar rumah merupakan sumbangan wanita dalam pembangunan ekonomi negara selain daripada meningkatkan taraf hidup keluarga mereka. Hal ini kerana golongan wanita mempunyai hak dan peranan yang sama dengan golongan lelaki (Wan Abdul Kadir 1998: 14). Justeru, penglibatan wanita dalam pekerjaan dapat ditonjolkan melalui hubungan kekeluargaan yang mementingkan sistem pewarisan seterusnya tidak kira sama ada lelaki mahupun wanita. Walau bagaimanapun, kebanyakan anak lelaki lebih cenderung memilih kerjaya lain daripada mengambil alih perusahaan keluarga. Oleh itu, dalam kes kajian ini, anak perempuan merupakan pewaris yang dianggap layak menyambung perniagaan batik dan songket. Pengaruh budaya niaga yang diwarisi secara turun-temurun daripada keluarga khususnya daripada ibu menyebabkan golongan wanita memonopoli aktiviti perniagaan di Kelantan dan Terengganu. Sementelahan juga peranan ibu bapa memberi impak penting ke atas anak-anak mereka. Didikan yang diberi keluarga berkaitan keusahawanan berjaya memupuk minat wanita menjadikan bidang keusahawanan sebagai kerjaya mereka.

Untuk memupuk pembangunan keusahawanan dalam kalangan golongan wanita, Program Transformasi Kerajaan merupakan elemen penting yang boleh memberi perubahan kepada taraf hidup mereka. Mengubah taraf hidup merupakan satu keperluan kepada wanita khususnya wanita yang mengetuai isi rumah. Peranan kerajaan boleh mencetuskan perubahan bagi wanita untuk memperolehi sumber pendapatan bagi menyara kehidupan selepas ketiadaan suami. Hasil kajian menunjukkan terdapat usahawan wanita yang terpaksa bekerja mencari pendapatan sampingan disebabkan pendapatan suami tidak mencukupi. Hal ini menunjukkan keusahawanan batik dan songket berupaya menyediakan peluang pekerjaan kepada wanita sebagai satu cara menyara keluarga.

Cadangan kajian susulan yang boleh dipertimbangkan perlu dikaji sejarah perusahaan batik dan songket di Pantai Timur yang lebih sinonim dengan golongan wanita. Aspek sejarah perkembangan batik dan songket di negara kita perlu diberi perhatian yang sewajarnya untuk dikaji dan diteliti sehingga industri ini dikenali sebagai industri kotej dalam kalangan wanita yang mencari sumber pendapatan sampingan. Selain itu, perlu kajian yang lebih terperinci mengenai isu penglibatan wanita dalam keusahawanan, khususnya wanita yang tidak memiliki tahap pendidikan tinggi dan tinggal di luar bandar. Salah satu sebab wanita terjun ke dalam dunia keusahawanan adalah disebabkan tidak mempunyai pendidikan yang tinggi untuk bekerja serta memiliki pendapatan bulanan yang tetap. Bagi menutup kekurangan dari segi pendidikan ini, wanita melibatkan diri mereka dalam keusahawanan kerana bidang ini tidak memerlukan syarat yang khusus untuk menceburinya.

\section{RUJUKAN}

Abd. Rasid Ismail \& Ahmadrashidi Hassan. 2012. Keindahan dalam reka bentuk motif seni hiasan tekstil tradisional Melayu: Satu analisa formalistik. The $9^{\text {th }}$ Regional Symposium of the Malay Archipelago (Simposium Nusantara 9)

Anis Solehin Hussain@ Othman \& Sharifah Rohayah Sheikh Dawood. 2020. Keusahawanan wanita di Kelantan berteraskan Model Ekonomi Baru: Hal tuju dan cabaran. Journal of Social Sciences and Humanities 17(4): 124-148.

Akter, M., Rahman, M. \& Radicic, D. 2019. Women Entrepreneurship in International Trade: Bridging the gap by bringing feminist theories into entrepreneurship and internationalization theories. Sustainability 11(22): 6230. MDPI AG.

Aquino, M. Maylene. 2017. The role new media on women entrepreneurship development in the Philippines: A research journal. MDC-UPOU ID No 2013-81920.

Bayisenge, R., Shengede, H., Harimana, Y., Karega, J. B., Lukileni, M., Muhammad Nasrullah, Xinrui, H. \& Nteziyaremye, B. E. 2020. Contribution of small and medium enterprises by women in generating employment opportunity in Rwanda. International Journal of Business and Management 15(3): 14-24.

Berita Harian. 2017. Industri 4.0 ubah cara kerja, hidup. Available at http://www.bharian.com.my, 20 November 2019.

Carranza, E., Dhakal, C. \& Love, I. 2018. Female entrepreneurs: How and why are they different? Job Working Paper Issue No.20, World Bank Group.

Chowdhury Dilruba Shoma. 2019. Financing female entrepreneurs in cottage, micro, small, and medium enterprises: Evidence from the financial sector in Bangladesh 2010-2018. Asia \& The Pacific Policy Studies 6: 397-416.

Ferrant, G., Pesando, L.M. \& Nowacka, K. 2014. Unpaid Care Work: The Missing Link in the Analysis of Gender Gaps in Labour Outcomes. OECD Development Centre.

Guest, G., Namey, E. \& Chen M. 2020. A simple method to assess and report thematic saturation qualitative research. PLoS ONE 15(5): 1-17.

Jabatan Statsitik Malaysia. 2020. Statistics on Women Empowerment in Selected Domains, Malaysia, 2020. Laman web rasmi Jabatan Statistik Malaysia.

Jariah Masud, Zumilah Zainalaludin \& Linda A. Lumayag. 2010. Wanita luar bandar: Daripada ladang keluarga ke perusahaan mikro. Himpunan makalah wanita dan pembangunan di Malaysia- Satu kesinambungan: Menyusuli perubahan selama empat dekad. Suatu projek akademik yang diilhamkan dan diselaraskan oleh Jamilah Ariffin. Petaling Jaya: MPH Group Publishing Sdn Bhd. 
Khatijah Omar, Muhammad Abi Sofian Abdul Halim, Marhana Mohamed Anuar, Nik Hazimah Nik Mat, Azlinzuraini Ahmad \& Zaleha Mohamad. 2018. A study on entrepreneurial intention and personality among female entrepreneurs in Kuala Nerus, Terengganu, Malaysia. Journal of Sustainability Science and Management 13(1): 229-236.

Kasseye Bayu, E. 2019. A comparartive analysis on the perspectives of African feminism VS Western feminism: Philosophical debate with their criticism and its implication for women's rights in Ethiopia context. International Journal of Sociology and Anthropology 11(4): 54-58.

Mansoor, A. 2016. Marginalization in third world feminism: Its problematics and theoretical reconfiguration. Palgrave Communications 2(1): 1-9

Mohd Nor Hakimin Yusoff \& Mohd Rafi Yaacob. 2010. Kajian awalan perbandingan aktiviti keusahawanan antara Kota Bharu, Kelantan dan Padang, Sumatera. Prosiding PERKEM V Jilid 2: 129-140.

Mohd Rafi Yaacob, Abu Hanifah Yusof \& Nik Mazlan Nik Husain. 2012. Cabaran usahawan Bumiputera kitar semula: Satu tinjauan di Kelantan dan Terengganu. Dalam Seminar Kebangsaan Kolej Komuniti, 31 Oktober - 1 November 2012, Putera World Trade Center (PWTC), Kuala Lumpur (Unpublished).

Mohd. Shariff, M.N., Keat, O.Y. \& Mamat, M.Z. 2004. Kecenderungan keusahawanan: Satu kajian empirikal di kalangan tenaga akademik politeknik-politeknik Malaysia. IJMS 11(2): 171-194.

Nascimento, L. C. N., Souza, T. V., Oliveira, I. C. S., Moraes, J. R. M. M., Aguiar, R. C. B. \& Silva, L. F. 2018. Theoretical saturation in qualitative research: An experience report in interview with schoolchildren. Rev Bras Enferm 71(1): 228-33.

Neelofer Habib, Ab Qayoom Shah, Syed Towseefah Rafique \& Bilal Ahmad Dar. 2019. Promoting women empowerment through cottage industries: A case study of Nikkas village of District Pulwama. The Research Journal of Social Sciences 10(4): 237-242.

Noor Rahamah $\mathrm{Hj} \mathrm{Abu}$ Bakar. 2009. Faktor-faktor yang mempengaruhi segregasi pekerjaan mengikut gender di Malaysia: Satu ilustrasi mikro. Malaysian Journal of Society and Space 5(2): 45-54.

Noor Raihani \& Abdullah Al Mamun. 2018. Entrepreneurial Competency, Competitive Advantage and Performance of Informal Women Micro-entrepreneurs in Kelantan, Malaysia. Journal of Enterprising Communities: People and Places in the Global Economy 12(3): 299-321.

Nor Aini Haji Idris. 2010. Wanita dalam perniagaan pasar: Kajian kes peniaga kecil wanita di Kelantan. Himpunan makalah wanita dan pembangunan di Malaysia- Satu kesinambungan: Menyusuli perubahan selama empat dekad. Suatu projek akademik yang diilhamkan dan diselaraskan oleh Jamilah Ariffin. Petaling Jaya: MPH Group Publishing Sdn Bhd.

Nor Hanim Awang @ Mohd Noor, Norfatiha Othman \& Nor Hayati Sa'at. 2021. Pembentukan Usahawan Kraftangan Wanita di Malaysia: Peranan Sikap, Warisan Keluarga dan Pembudayaan Nilai Agama. Kajian Malaysia [early view].

Nor Hanim Awang @ Mohd Noor. 2018. Peranan gender dan budaya dalam membentuk usahawan batik dan songket wanita di Pantai Timur. Tesis Doktor Falsafah. Universiti Malaysia Terengganu.
OECD. 2020. Gender-Specific Consumption Patterns, Behaviourial Insights, and Circular Economy. 2020 Global Forum on Environment: Mainstreaming Gender and Empowering Women for Environmental Sustainability, Paris, 5-6 March 2020.

Ojdiran, F. \& Anderson, A. 2020. Womens's entrepreneurship in the global south: Empowering and emancipating? Administrative Sciences, MDPI 10(87): 1-22.

Ong, C. 1970. Patterns and Pattern-Making Technique in Traditional Textile of Southeast Asia. Singapore: University of Singapore.

Othman Lebar. 2009. Penyelidikan Kualitatif: Pengenalan kepada Teori dan Metod. Tanjong Malim: Penerbit Universiti Pendidikan Sultan Idris.

Othman, A.S \& Dawood, S.R. 2020. Keusahawanan wanita di Kelantan berteraskan model Ekonomi Baru: Hala tuju dan cabaran. e-Bangi: Journal of Social Sciences and Humanities 17(4):124-148.

Parkinson, B. K. 1967. Non-economic factors in the economic retardation of the rural Malays. Modern Asian Studies 1(1): 31-46.

Perbadanan Kraftangan Malaysia Cawangan Kelantan. 2015. Senarai Usahawan di Daerah Kota Bharu, Kelantan. Kelantan: Kota Bharu.

Perbadanan Kraftangan Malaysia Cawangan Terengganu. 2015. Senarai Usahawan di Daerah Kuala Terengganu, Terengganu. Terengganu: Kuala Terengganu.

Resurreccion, P. F. \& Rosario, R. V. D. 2012. Entrepreneurial competencies and work-life balance of rural women entrepreneur: Evidence from the Philippines. Journal of Sociological Research 3(2): 544-555.

Rosman Mahmood \& Mohd Rosli Mohamad. 2011. Perusahaan Kecil dan Dilema Usahawan Melayu. Kuala Lumpur: Penerbit Universiti Malaya.

Sharifah Nazira Syed Idros. 2012. Kajian terhadap faktorfaktor penyumbang kepada kejayaan dan penglibatan usahawan wanita di kawasan Lembah Klang. Tesis Sarjana. Universiti Utara Malaysia.

Suhail M.G., McElwee, G. \& Omar, D. 2019. Entrepreneurial success of cottage-based women entrepreneurs in Oman. International Journal of Entrepreneurial Behavior \& Research 25(3): 480-498.

Sweet, J. A. 1973. Women in the Labor Force. New York: Seminar Press.

Tomos F., Aggrawal A., Thurairaj S., Balan O.C., HyamsSsekasi D. 2020. Effects of culture on women entrepreneurs' success: A cross-country study. Dlm. Gender Studies, Entrepreneurship and Human Capital, disunting oleh Paoloni P., Lombardi R. IPAZIA 2019. Springer Proceedings in Business and Economics. Springer, Cham.

Tomos, F. \& Thurairaj, S. 2019. New emerging technologies and ICT and their impact on women entrepreneurs' succsess. Dlm. Women Entrepreneurs and Strategic Decision Making in the Global Economy, disunting oleh F. Tomos, N. Kumar, N. Cliffton \& D. Hyams-Ssekasi, 44166. Hershey: IGI Global.

Wan Abdul Kadir Yusoff. 1998. Nilai dan world-view orang Melayu tentang gender. Dlm. Gender, Budaya dan Masyarakat, disunting oleh Rokiah Talib \& Shanthi Thambiah. Kuala Lumpur: Rancangan Pengajian Gender, Fakulti Sastera dan Sains Sosial, Universiti Malaya. 
Wan Hashim Wan Teh. 1996. Malay Handicraft Industries: Origins and Development. Ampang/Hulu Kelang, Selangor: Percetakan Dewan Bahasa dan Pustaka.

Zaimah, R. \& Sazuani Abdullah. 2017. Tahap keupayaan usahawan dalam perusahaan kecil dan sederhana di Kuala Terengganu. Malaysian Journal of Society and Space 13 (Issue 4): 117-125.

Zarina Md Nor \& Zuraida Ramli. 2016. A glimpse at women entrepreneurs in Penang. Akademika 86(2): 79-86.

Nor Hanim Awang @ Mohd Noor

Fakulti Perniagaan, Ekonomi dan Pembangunan Sosial

Universiti Malaysia Terengganu

21030 Kuala Nerus, Terengganu, MALAYSIA.

E-mel: hanim850701@gmail.com
Norfatiha Othman (penulis koresponden)

Fakulti Perniagaan, Ekonomi dan Pembangunan Sosial Universiti Malaysia Terengganu

21030 Kuala Nerus, Terengganu, MALAYSIA.

E-mel: norfatiha.othman@umt.edu.my

Nor Hayati Sa'at

Fakulti Perniagaan, Ekonomi dan Pembangunan Sosial Universiti Malaysia Terengganu

21030 Kuala Nerus, Terengganu, MALAYSIA.

E-mel: norhayati@umt.edu.my

Roslina Ismail

Fakulti Perniagaan, Ekonomi dan Pembangunan Sosial Universiti Malaysia Terengganu

21030 Kuala Nerus, Terengganu, MALAYSIA.

E-mel: roslina@umt.edu.my 